\title{
Cancer risk in inflammatory bowel disease
}

\author{
ANDERS M EKBOM MD PHD
}

\begin{abstract}
АM ЕКвОМ. Cancer risk in inflammatory bowel disease. Can J Gastroenterol $1995 ; 9(1): 23-26$. There is an increased risk of cancer in both ulcerative colitis and Crohn's disease. In 3121 patients with ulcerative colitis, 225 cases of cancer were diagnosed compared with 142.1 expected (standardized incidence ratio [SIR] 1.6, 95\% CI 1.4 to 1.8), and in 1655 patients with Crohn's disease, 58 cases of cancer were detected compared with 47.1 expected (SIR 1.2, 95\% CI 0.9 to 1.6). After excluding colorectal cancer the observed number of malignancies was very close to that expected for ulcerative colitis (SIR 1.0, 95\% CI 0.9 to 1.2 ) and for Crohn's disease (SIR 1.1, 95\% CI 0.8 to 1.5). Thus, the increased risk of cancer in inflammatory bowel disease is confined to colorectal cancer. In Crohn's disease 12 cases of colorectal cancer were observed (SIR 2.5, 95\% CI 1.3 to 4.3 ). The increased risk was confined to those with colonic involvement and young age at diagnosis. In patients with colonic involvement and younger than age 30 years at diagnosis, the SIR was 20.9 (95\% CI 6.8 to 48.7 ) versus 2.2 for those older than 30 years at diagnosis ( $95 \% \mathrm{CI} 0.6$ to 5.7). In ulcerative colitis 91 cases of colorectal cancer were observed with an SIR of 5.7 (95\% CI 4.6 to 7.0$)$. Extensive disease and young age at diagnosis were independent risk factors. Pancolitis at diagnosis resulted in an SIR of 14.8 (95\% CI 11.4 to 18.9), 2.8 in left-sided colitis (95\% CI 1.6 to 4.4 ) and 1.7 in proctitis ( $95 \%$ CI 0.8 to 3.2 ). There is great variation in the risk estimates in different studies worldwide. Different treatment strategies could be an explanation, a hypothesis that was substantiated in a study of 102 cases of colorectal cancer among patients with ulcerative colitis compared with 196 controls. Pharmacological therapy with sulfasalazine entailed a strong protective effect against colorectal cancer (relative risk of $0.34,95 \%$ CI 0.190 to 0.62 ).
\end{abstract}

Key Words: Cancer, Colorectal cancer, Crohn's disease, Inflammatory bowel disease, Ulcerative colitis

\section{Risque de cancer dans la maladie inflammatoire de l'intestin}

RÉSUMÉ : La colite ulcéreuse et la maladie de Crohn s'accompagnent toutes deux d'un risque accru de cancer. Chez 3121 patients atteints de colite ulcéreuse, 225 cas de cancer ont été diagnostiqués contre 142,1 prévisibles (ratio d'incidence standardisé [RIS] 1,6, 95 \% IC 1,4 à 1,8) et chez 1655 patients atteints de la

voir page suivante

University Hospital, Cancer Epidemiology Unit, Uppsala, Sweden

Correspondence: Dr Anders M Ekbom, University Hospital, Cancer Epidemiology Unit, S-751, 85 Uppsala, Sweden

This paper was presented at the Trends in Inflammatory Bowel Disease Therapy meeting, April 6 to 9, 1994, held in Victoria, British Columbia. This paper has also been published in Sutherland LR, et al, eds. Inflammatory Bowel Disease: Basic Research, Clinical Implications and Trends in Therapy. Boston, Dordrecht and London: Kluwer Academic Publishers, 1994
$A_{\text {in different sites and inflamma- }}^{\text {nassociation between cancer }}$ tory bowel disease (IBD) has been reported in many studies dating from the 1920s (1). Associations between every conceivable site and type have been proposed. There are, however, very few population-based studies with a size sufficiently large to give reliable risk estimates. In most instances the relationship between IBD and different malignancies has emanated from either small case series or follow-up studies of patient groups where the selection bias is a concern that most authors have not taken into consideration. It is also worth pointing out that between 20 and $30 \%$ of any population in western countries will be diagnosed with some sort of cancer during their life. Thus, to ensure reliable risk estimates there is a need for a control population, and such studies have to be performed outside referral centres where selection bias can be operating.

In a population-based study of 3121 patients with ulcerative colitis and 1655 patients with Crohn's disease the author's group (2) confirmed an overall increased risk of cancer both among patients with ulcerative colitis - $202 \mathrm{ob}$ served cases of cancer compared with 142.1 expected (standardized incidence ratio [SIR] 1.6, 95\% CI 1.4 to 1.8$)$ - and with Crohn's disease - 58 observed cases compared with 47.1 expected (SIR 1.2, 95\% CI 0.9 to 1.6).

Surveillance bias could be a concern in a cohort of patients with regular contacts with the health care system. How- 
maladie de Crohn, 58 cas ont été décelés contre 47,1 prévisibles (RIS 1,2, $95 \%$ IC 0,9 à 1,6 ). Après l'exclusion du cancer recto-colique, le nombre observé de néoplasies a été près des chiffres prévisibles pour la colite ulcéreuse (RIS 1,0, 95 \% IC 0,9 à 1,2) et pour la maladie de Crohn (RIS 1,1,95 \% IC 0,8 à 1,5). Ainsi, le risque accru de cancer dans la maladie inflammatoire de l'intestin se limite au cancer recto-colique. Dans la maladie de Crohn, 12 cas de cancer recto-colique ont été observés (RIS 2,5,95\% IC 1,3 à 4,3). Le risque accru a été limité à ceux qui avaient une atteinte du côlon et qui étaient jeunes au moment du diagnostic. Chez les patients qui manifestaient une atteinte du côlon et qui avaient moins de 30 ans au moment du diagnostic, le RIS a été de 20,9 (95\% IC 6,8 à 48,7), contre 2,2 chez les sujets âgés de plus de 30 ans au moment du diagnostic (95\% IC 0,6 à 5,7). Dans la colite ulcéreuse, 91 cas de cancer recto-colique ont été observés avec un RIS de 5,7 (95 \% IC 4,6 à 7,0). L'étendue de la maladie et l'âge jeune au moment du diagnostic ont été des facteurs de risque indépendants. La pancolite au moment du diagnostic a donné lieu à un RIS de 14,8 (95 \% IC 11,4 à 18,9), 2,8 dans la colite latérale gauche (95\% IC 1,6 à 4,4) et 1,7 dans la proctite ( $95 \%$ IC 0,8 à 3,2). On note une grande variation dans les estimations du risque si l'on compare différentes études à travers le monde. Le recours à des stratégies thérapeutiques différentes pourrait fournir un élément d'explication, hypothèse qui a été renforcée dans une étude sur 102 cas de cancer recto-colique parmi des patients porteurs de colite ulcéreuse, en comparaison avec 196 témoins. Le traitement pharmacologique à l'aide de sulfasalazine a semblé conférer une protection appréciable contre le cancer recto-colique (risque relatif de 0,34, $95 \%$ IC 0,190 à 0,62 ).

ever, the standardized mortality ratio (SMR) was also increased for malignant diseases. In the case of ulcerative colitis the SMR was 1.3 (95\% CI 1.1 to 1.6 ) and 1.1 for Crohn's disease (95\% CI 0.7 to 1.6). After excluding colorectal cancer the relative risk (RR) for cancer was close to 1.0 for both ulcerative colitis (SIR 1.0, 95\% CI 0.9 to 1.2) and Crohn's disease (SIR 1.1, 95\% CI 0.8 to 1.5). The risk estimate was almost the same: the SMR was 1.0 for ulcerative colitis (95\% CI 0.7 to 1.5 ) and 0.9 for Crohn's disease (95\% CI 0.8 to 1.3 ). Colorectal cancer therefore seems to be the major cause of the increased morbidity and mortality in malignancies in patients with IBD.

There was a tendency towards an increased risk of cancer of the bile ducts among patients with extensive colitis (SIR $1.9,95 \%$ CI 1.7 to 4.0 ), which is consistent with other studies $(3,4)$, and an increased risk of cancer of the small intestine among patients with Crohn's disease (SIR 3.4, 95\% CI 0.1 to 18.6), also similar to previous reports $(5,6)$. The risk estimate in the study from the Uppsala Health Care Region, Sweden (2) is, however, lower than previously reported. One feasible explanation is similar to previous studies from New York (10) and Cleveland (3).

The risk of colorectal cancer among patients with Crohn's disease varies greatly in different studies, with risk estimates between 2.5 and $20.0(6,11$ 13). In the study from the Uppsala Health Care Region the author and co-workers (13) found an overall increased risk of 2.5 for patients with Crohn's disease (95\% CI 1.3 to 4.3 ). There was no difference between females and males. However, in patients in whom the disease was confined to terminal ileum at diagnosis, the risk of colorectal cancer did not differ from that of the background population. On the other hand, patients with any colonic involvement at diagnosis had a substantially increased risk (SIR 5.6, 95\% CI 2.1 to 12.2).

Age at diagnosis also seemed to affect the risk estimates substantially. In those with any colonic involvement and diagnosis before age 30 years, an SIR of 20.9 was observed (95\% CI 6.8 to 48.7) compared with 2.2 (95\% CI 0.6 to 5.7) among those diagnosed after age 30 years. This is consistent with results from a Mayo Clinic study (11) where an overall risk of 20.0 was found as $80 \%$ of their patients had colonic involvement at diagnosis.

As for Crohn's disease, the risk estimates given in different studies of the risk of colorectal cancer in patients with ulcerative colitis vary substantially. However, with the exception of two Danish studies $(14,15)$, an increased risk has been found in all other studies $(3,4,16-27)$. The cumulative incidence 25 to 35 years after diagnosis ranges from $8 \%(6)$ to $43 \%$ (18), and SIRs vary from 2 (26) to $30 \%$ (25). In a multivariate analysis from the Uppsala study (16), age at diagnosis was found to be an independent factor for an increased risk of colorectal cancer. Young age (younger than 15 years) entailed a cumulative incidence 35 years after diagnosis of $40 \%$, which is very close to that reported from the Mayo Clinic (18), a study also confined to patients younger than age 15 years at diagnosis. Further follow-up of patients in the Uppsala study (unpublished data) has revealed that $50 \%$ of all patients with 
pancolitis diagnosed before age 15 years will be diagnosed with a colorectal cancer before age 50 years. These findings suggest that a prophylactic proctocolectomy in this patient group might be an appropriate alternative compared with close surveillance in order to reduce the mortality in colorectal cancer, which is the main reason for the reduced long term relative survival in patients with ulcerative colitis (28).

It has been proposed that a patient with ulcerative colitis is at maximum risk of development of colorectal cancer at approximately age 50 years regardless of age at onset or duration of disease (22). In the Uppsala study, the author and colleagues (16) were unable to confirm that hypothesis. They found a consistently higher RR than for the normal population persisting among patients even after age 70 years, which seems to refute that hypothesis.

Extent of disease at diagnosis is also an independent risk factor of colorectal cancer (16). Patients with proctitis did not differ significantly in the risk of colorectal cancer from the background population (SIR 1.7, 95\% CI 0.8 to 3.2 ) even after analyzing rectal cancer as a single entity. These findings imply that it is not the inflammation as such, but some additional exposure that is needed for a malignant transformation in this patient group. The increased risk of colorectal cancer among patients with left-sided colitis at diagnosis has been confirmed $(21,27)$. In the analysis of the results from the Uppsala study (16), this increased risk was also found although the risk estimate was substantially lower (SIR 2.8, 95\% CI 1.6 to 4.4) compared with patients with pancolitis at diagnosis (SIR 14.8, 95\% CI 11.4 to 188.4). Moreover, the latency period seems to be 10 to 15 years longer compared with pancolitis before a patient with left-sided colitis is at an increased risk of colorectal cancer (Figure 1). Whether this increased risk is due to patients initially diagnosed with left-sided colitis in which the disease subsequently progressed to pancolitis, or the risk is present among patients with disease confined to the left colon remains unknown.

In one of the two studies in which

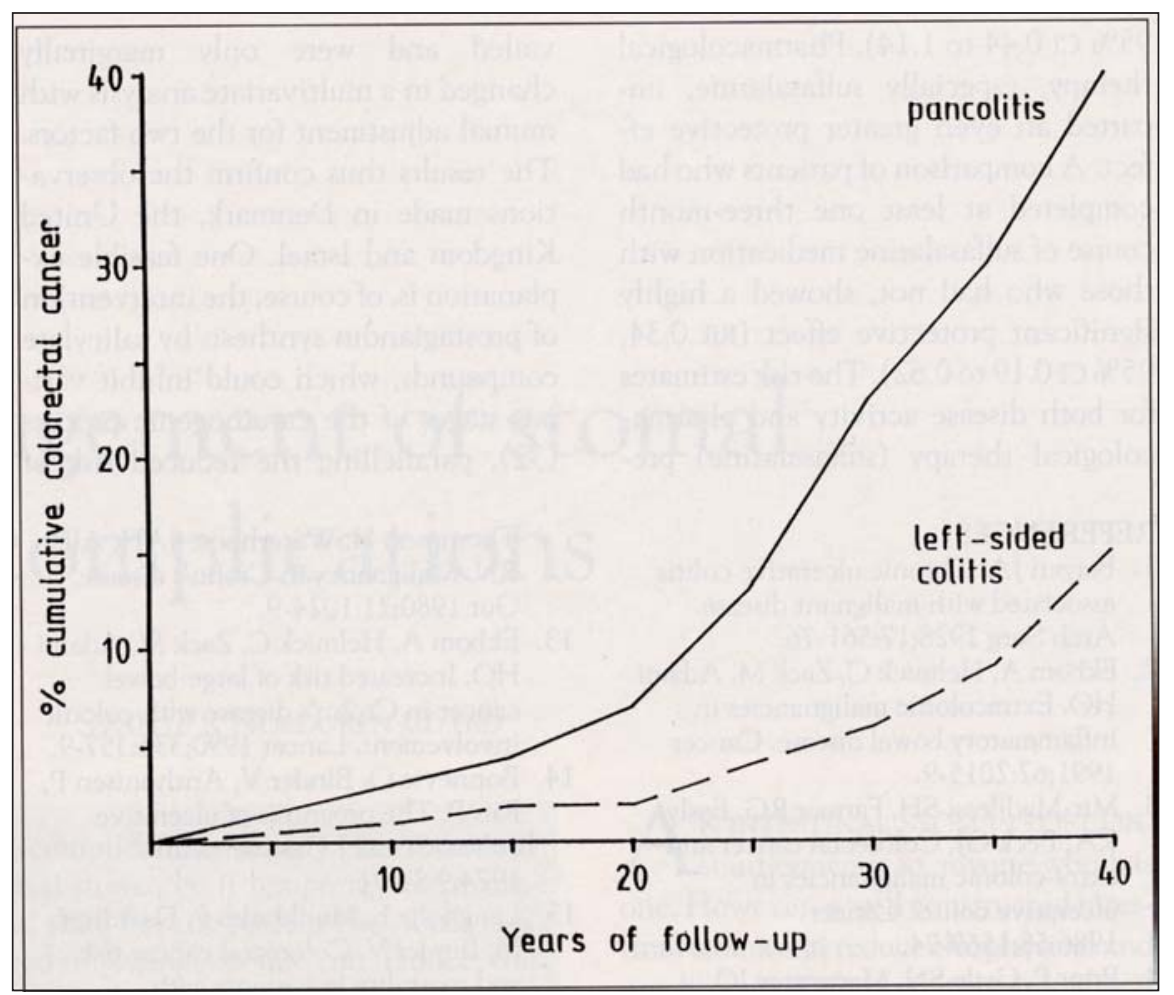

Figure 1) Cumulative incidence of colorectal cancer for patients with pancolitis and left-sided colitis at diagnosis

no association was found between ulcerative colitis and colorectal cancer (14), the lack of association was probably due to the short follow-up - 10 or fewer years after diagnosis. In the other study (15), however, the follow-up was substantially longer although the authors analyzed left-sided colitis and pancolitis as one entity which, at least partly, may explain the lack of association found. These authors suggest an alternative explanation: that modern treatment strategies using pharmacological compounds such as sulfasalazine could be one reason for the lack of any increased risk of colorectal cancer in their patient group. The same observation was also made in a study from the United Kingdom (29) of colonoscopic surveillance among patients with ulcerative colitis. These authors noted: "A review of the notes of our cancer patients suggests that virtually none of them were taking disease suppressive drugs, such as salazopyrin, regularly or at all”. Moreover, a similar mechanism was proposed in the 1980s (30). To study whether additional risk factors or protective agents could be identified for colorectal cancer among patients with ulcerative colitis, Pinczowski et al (31) recently conducted a case-control study. Cases were found by a renewed follow-up of a previous study (16). They identified 102 patients diagnosed with colorectal cancer after a previous diagnosis of ulcerative colitis. Two controls were identified for each case and were matched for sex, extent of disease at diagnosis and calendar year of ulcerative colitis diagnosis. Moreover, the controls had to be alive without colorectal cancer and with an intact or partly intact colon when the case's colorectal cancer was diagnosed. Six controls were excluded due to a proctocolectomy done before diagnosis of colorectal cancer in the case, leaving 196 controls. After retrieving the charts from cases and controls in a uniform manner, the extent to which pharmacotherapy and disease activity, among other things, had an impact on the risk of colorectal cancer was determined.

Disease activity imparted a protective effect when those with more than one exacerbation on average per year 
were compared with those with fewer than one. Those with a higher disease activity had a decreased risk (RR $0.70,95 \%$ CI 0.44 to 1.14 ). Pharmacological therapy, especially sulfasalazine, imparted an even greater protective effect. A comparison of patients who had completed at least one three-month course of sulfasalazine medication with those who had not, showed a highly significant protective effect (RR 0.34, 95\% CI 0.19 to 0.62).

\section{REFERENCES}

1. Bargen JA. Chronic ulcerative colitis associated with malignant disease. Arch Surg 1928;17:561-76.

2. Ekbom A, Helmick C, Zack M, Adami $\mathrm{HO}$. Extracolonic malignancies in inflammatory bowel disease. Cancer 1991;67:2015-9.

3. Mir-Madjlessi SH, Farmer RG, Easly KA, Beck GJ. Colorectal cancer and extra-colonic malignancies in ulcerative colitis. Cancer 1986;58:1569-74.

4. Prior P, Gyde SN, Macartney JC, Thompson H, Waterhouse JAH, Allan $\mathrm{RN}$. Cancer morbidity in ulcerative colitis. Gut 1982;23:490-7.

5. Senay E, Sachar DB, Keohane M, Greenstein AJ. Small bowel carcinoma in Crohn's disease. Distinguishing features and risk factors. Cancer 1989;63:360-3.

6. Greenstein AJ, Sachar DB, Smith H, Janowitz HD, Aufses AH. A comparison of cancer risk in Crohn's disease and ulcerative colitis. Cancer 1981;48:2742-5

7. Fireman Z, Grossman A, Lilos P, et al. Intestinal cancer in patients with Crohn's disease. Scand J Gastroenterol 1989;24:346-50.

8. Israel K, Nissenblatt M. Association of inflammatory bowel disease (IBD) with indolent soft-tissue sarcomas: Report of two cases and review of literature. J Surg Oncol 1986;32:125-30.

9. Lindberg E, Tysk C, Andersson K, Järnerot $G$. Smoking and inflammatory bowel disease: A case control study. Gut 1988;29:352-7.

10. Greenstein J, Gennuso R, Sachar DB, et al. Extraintestinal cancers in inflammatory bowel disease. Cancer 1985;56:2914-21.

11. Weedon DD, Shorter RG, Ilstrup DM, Huizenga KA, Taylor WF. Crohn's disease and cancer. N Engl J Med 1973;289:1099-102.

12. Gyde SN, Prior P, Macartney JC,
The risk estimates for both disease activity and pharmacological therapy (sulfasalazine) prevailed and were only marginally changed in a multivariate analysis with mutual adjustment for the two factors. The results thus confirm the observations made in Denmark, the United Kingdom and Israel. One feasible explanation is, of course, the intervention of prostaglandin synthesis by salicylate compounds, which could inhibit various stages of the carcinogenic

Thompson H, Waterhouse JAH, Allan RN. Malignancy in Crohn's disease. Gut 1980;21:1024-9.

13. Ekbom A, Helmick C, Zack M, Adami $\mathrm{HO}$. Increased risk of large-bowel cancer in Crohn's disease with colonic involvement. Lancet 1990;336:357-9.

14. Bonnevie O, Binder V, Anthonisen P, Riis $\mathrm{P}$. The prognosis of ulcerative colitis. Scand J Gastroenterol 1974;9:81-91.

15. Langholtz E, Munkholm P, Davidsen $\mathrm{M}$, Binder V. Colorectal cancer risk and mortality in patients with ulcerative colitis. Gastroenterology 1992;103:1444-51.

16. Ekbom A, Helmick C, Zack M, Adami $\mathrm{HO}$. Ulcerative colitis and colorectal cancer. A population-based study. N Engl J Med 1990;323:1228-33.

17. Broström $O$, Löfberg R, Nordenvall B, Öst $\AA$, Hellers G. The risk of colorectal cancer in ulcerative colitis: an epidemiologic study. Scand J Gastroenterol 1987;22:1193-9.

18. Devroede GI, Taylor WF, Saucer WG, Jackman RJ, Stickler GB. Cancer risk and life expectancy of children with ulcerative colitis. N Engl J Med 1971;285:17-21.

19. Edwards FC, Truelove SC. The course and prognosis of ulcerative colitis. IV. Carcinoma of the colon. Gut 1964;5:15-22

20. Gilat T, Fireman Z, Grossman A, et al. Colorectal cancer in patients with ulcerative colitis: a population study in central Israel. Gastroenterology 1988;94:870-7.

21. Greenstein A, Sachar D, Smith H, et al. Cancer in universal and left-sided ulcerative colitis: factors determining risk. Gastroenterology 1979;77:290-4.

22. Gyde SN, Prior P, Allan RN, et al. Colorectal cancer in ulcerative colitis: a cohort study of primary referrals from three centres. Gut 1988;29:206-17.

23. Katzka I, Brody R, Morris E, Katz S. process (32), parallelling the reduced risk of sporadic colorectal cancer in acetylsalicylic acid users (33).

\section{CONCLUSIONS}

Colorectal cancer in patients with ulcerative colitis is the only malignancy that has any impact on the morbidity and mortality in cancer in patients with IBD. This increased risk can be reduced through pharmacological therapy.

Assessment of colorectal cancer risk in patients with ulcerative colitis: experience from a private practice. Gastroenterology 1983;85:22-9.

24. Kewenter J, Ahlman H, Hultén L. Cancer risk in extensive ulcerative colitis. Ann Surg 1978;188:824-8.

25. Lennard-Jones JE, Morson BC, Ritchie JK, Williams CB. Cancer surveillance in ulcerative colitis: experience over 15 years. Lancet 1983;ii:149-53.

26. Maratka Z, Nedbal J, Kocianova J, Havelka J, Kudrmann J, Hendl J. Incidence of colorectal cancer in proctocolitis: a retrospective study of 959 cases over 40 years. Gut 1985;26:43-9.

27. Samuelsson SM. Ulcerös colit och proctit. Uppsala: University of Uppsala, Department of Social Medicine, 1976. (Thesis)

28. Ekbom A, Helmick CG, Zack M, Holmberg L, Adami HO. Survival and causes of death in patients with inflammatory bowel disease.

A population-based study. Gastroenterology 1992;103:954-60.

29. Lynch DAF, Lobo AJ, Sobala GM, Dixon MF, Axon ATR. Failure of colonoscopic surveillance in ulcerative colitis. Gut 1993;34:1075-80.

30. Odes HS, Fraser D. Ulcerative colitis in Israel: Epidemiology, morbidity and genetics. Public Health Rev 1989/90;17:297-319.

31. Pinczowski D, Ekbom A, Baron J, Yuen J, Adami HO. Risk factors for colorectal cancer among patients with ulcerative colitis - a case-control study. Gastroenterology 1994;107:117-20.

32. Marmett L. Aspirin and the potential role of prostaglandins in colon cancer. Cancer Res 1992;52:5575-89.

33. Thun M, Namboodiri N, Heath CJ. Aspirin use and reduced risk of fatal colon cancer. N Engl J Med 1991;325:1593-6. 


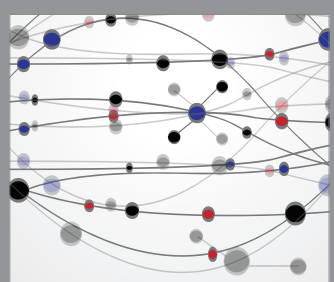

The Scientific World Journal
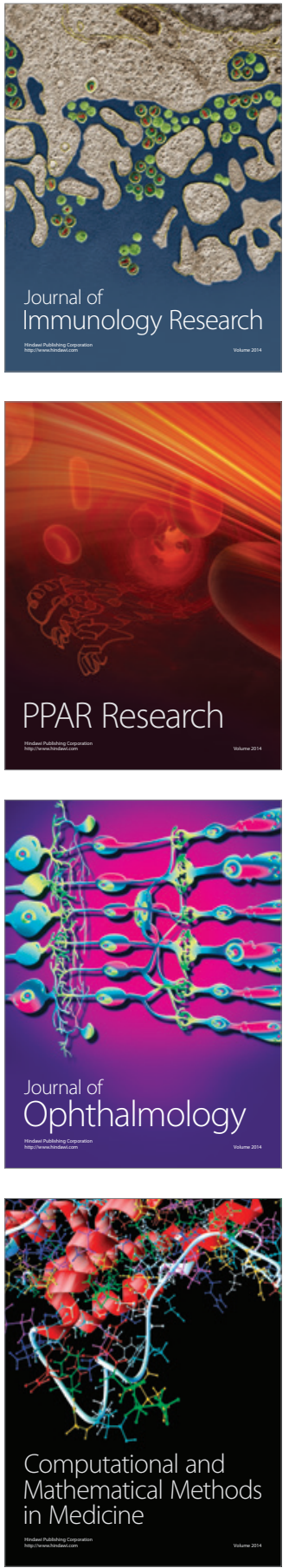

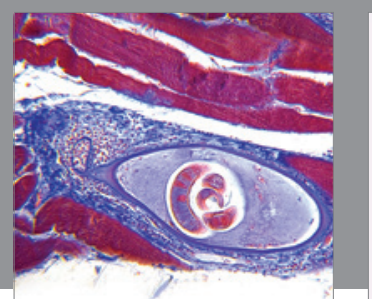

Gastroenterology Research and Practice

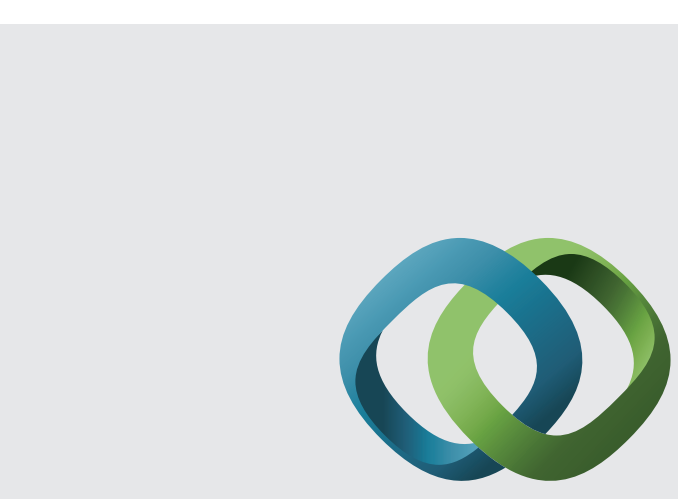

\section{Hindawi}

Submit your manuscripts at

http://www.hindawi.com
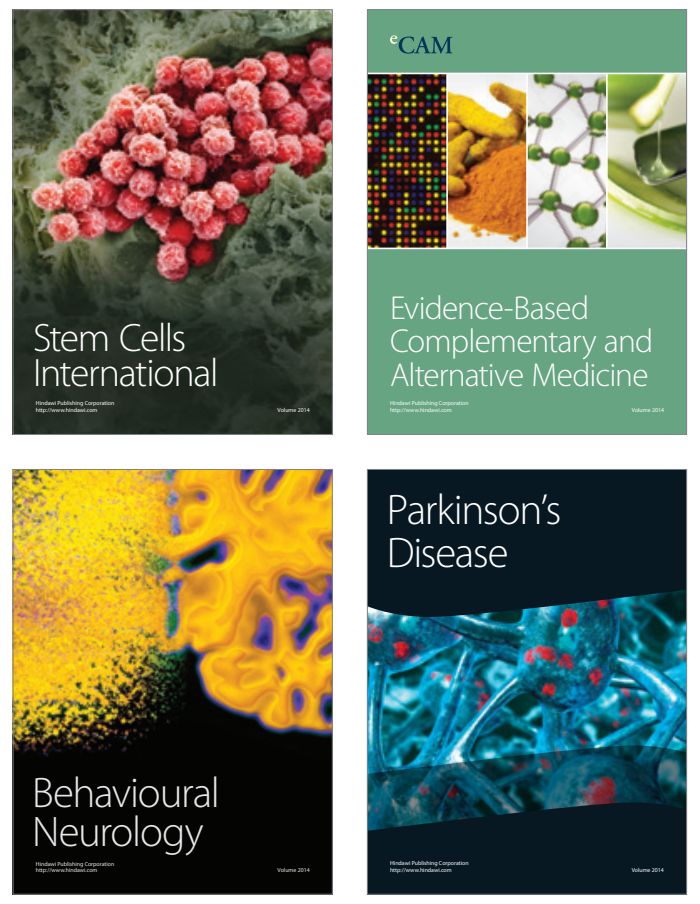
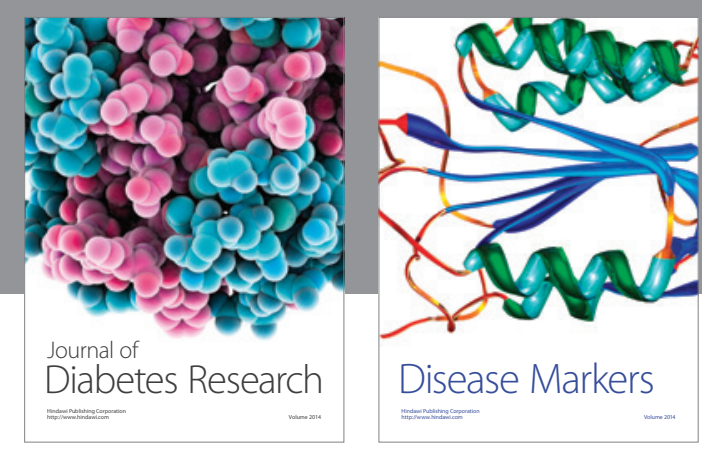

Disease Markers
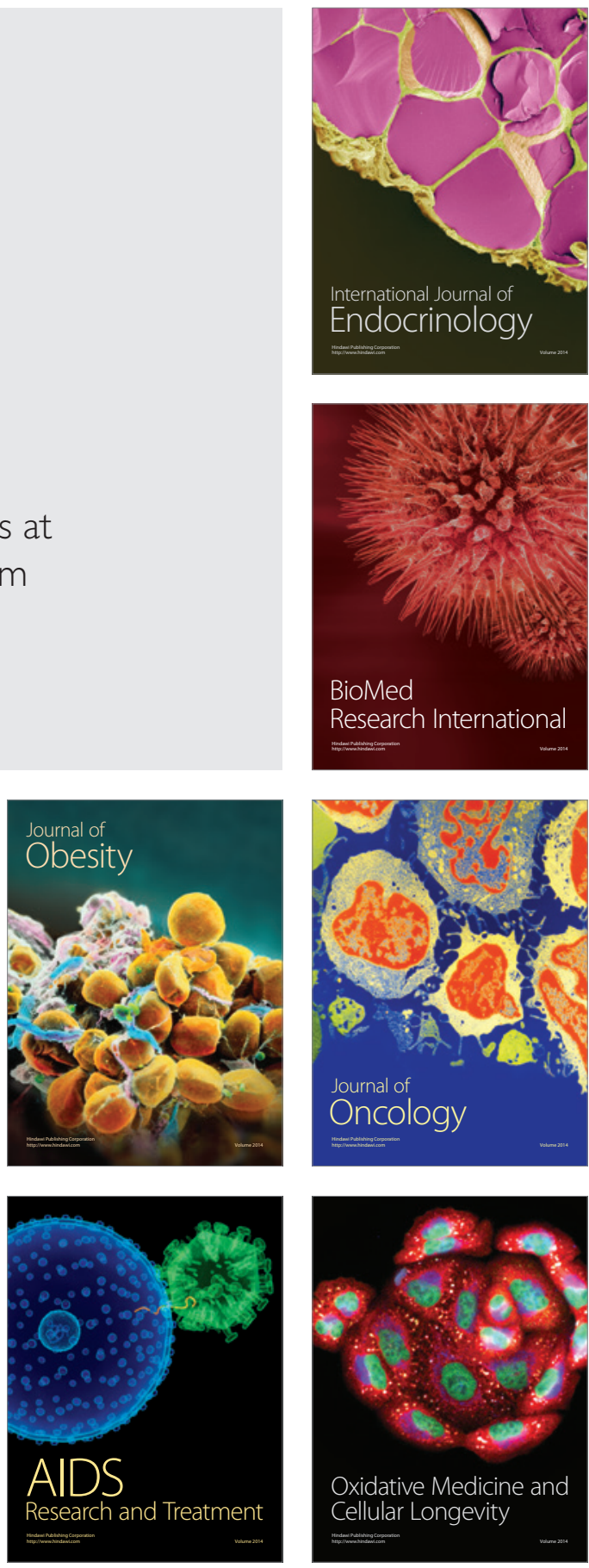